\title{
Polarographic Studies with the Improved Dipping Type Molybdenum Microelectrode. \\ (I) Polarography in aqueous solution.
}

\author{
By \\ Makoto SAITô \\ Department of Chemistry, College of General Eduction, Tohoku University, Sendai, Japan
}

(Received May 30, 1964)

The polarographic behavior of a number of ions was studied by use of an improved dipping type microelectrode. Cathodic waves were obtained from the solution of hydrogen and various metal ions, and an anodic wave from hydroxyl ion. The wave heights were directly proportional to the concentration of the reducible species. For example, the ratios of the limiting currents to the concentrations of metal ions were $1.00 \times 10^{4}$ and $1.08 \times 10^{4} \mu \mathrm{A} / M$ for $\mathrm{Cd}(\mathrm{II})$ and $\mathrm{Co}(\mathrm{II})$ ions, respectively. The applied voltage plotted against $\log \left(i_{d}-i\right) / i$ gave a straight line, but the slope of the straight line showed a larger value than the theoretical value which is expected when the electrode reaction is reversible. The half-wave potential remained nearly constant with the change of the concentration of reducible species and of the scanning rate of applied voltage. An AC polarographic peak was not observed for cobaltous ion with this electrode.

\section{Introduction}

The dipping type microelectrode has been used by several investigators. ${ }^{1,2), 3), 4,5)}$ Hills $e$ al..$^{5}$ stated that the polarogram obtained with the dipping type platinum microelectrode is similar to that obtained by the dropping mercury electrode and that a linear relationship is established between the applied voltage and $\log \left(i_{d}-i\right) / i$. Further, they stated that the surface area of the electrode and process of diffusion are more easily treated at a flat electrode than a needle-shaped one and the flat electrode is more convenient for the theoretical analysis by means of the Ilkovic equation. Flat electrode, however, cannot be used over a long period of time in the fused salt, because of the drastic corrosion of lead glass used for sealing the platinum wire. In this point, the needle-type electrode is more favorable, because the surface area of the glass which is in contact with the fused salt is smaller than that of the flat electrode. However, the wave from or height of polarogram obtained with the needle-type electrode is poorer in reproducibility than that with the flat electrode, because the electrode surface in contact with the solution, or the diffusion layer, varies with the change in the rate of gas passage over the cathode surface. These defects are eliminated by use of an improved needle-type electrode as described in this paper and it can be applied to the electrolysis in various fused salts including fluoride. Molybdenum wire which is commonly used as a cathode for the fused salt electrolysis was tried in this work. In the present work, using this electrode the fundamental investigation on polarographic behaviours of various ions were carried out and the adaptability for the polarographic study in the aqueous solution was discussed. 


\section{Experimental}

\section{1-1. Equipments and reagents.}

\section{I-1.1. Polarographic instrument.}

Yanagimoto pen-recording DC polarograph was used in the present series of experiments. Its polarization rate is $3.2 \mathrm{mV} / \mathrm{sec}$. Also a Yanagimoto pen-recording AC polarograph was used. Its $\mathrm{DC}$ potential scan rate was $2.66 \mathrm{mV} / \mathrm{sec}$.

\section{I-1.2. Electrolytic cell.}

For the studies of polarography in fused salt, an electrolytic cell as shown by (A) in Fig. 1, was used. An inner cell $35 \mathrm{~mm}$ in diameter and $100 \mathrm{~mm}$ in length, which was used for the exchange of electrolytic solution, was inserted into the outer cell.

\section{1-1.3. Description of electrodes.}

(a) Dipping type molybdenum microelectrode: Molybdenum wire $(0.3 \mathrm{~mm} \phi)$ was sealed into a borosilicate glass tube of $2 \mathrm{~mm}$ in diameter, as shown in Fig. 1(A), and this was inserted into quartz tube. The lower part of the quartz tube was widened and the tip coming in contact with the solution was opened into an orifice of $7 \mathrm{~mm}$ diameter, with an angle of about $45^{\circ}$, as shown in Fig. 1(B). The molybdenum wire was extruded by $0.1-0.5 \mathrm{~mm}$ from the top of the bubble formed

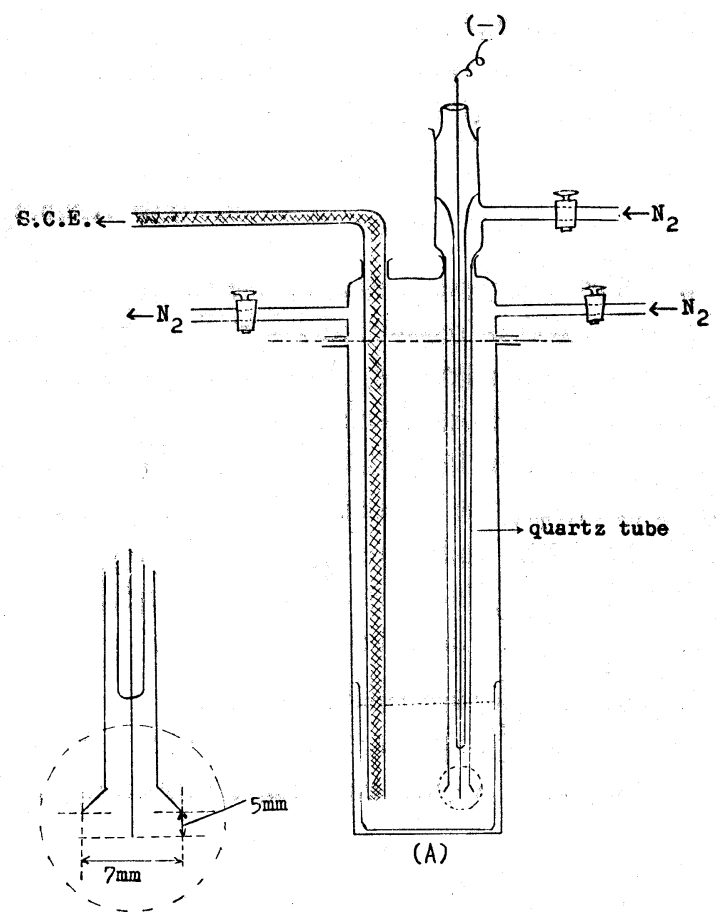

(B)

Fig. 1. Electrolytic cell and dipping type molybdenum microelectrode. by passage of an inert gas. This form was adopted in order to maintain the surface area of molybdenum coming into contact with the solution constant unaffected by the changes in the gas flow rate and also to minize the observed oscillations. By constructing the electrode in this shape, its sensitivity has increased several folds than that of the old type.?

The electrode used for the present experiment was found to satisfy the foregoing conditions when it had extruded by $5 \mathrm{~mm}$ from the tip of the quartz tube; and such an electrode gave well-defined polarograms. The surface was polished with emery paper No. 05, washed with aqua regia for a few seconds, and rinsed well with distilled water. Moisture on the surface was removed with a filter paper and the fully dried electrode was used.

(b) Reference clectrode: Saturated calomel reference electrode which is usually used in aqueous polarography was prepared ${ }^{6)}$ and used after its potential became sufficiently stable. A thirty per cent potassium chloride-agar brigde was used for the junction between electrolytic solution and reference electrode. 


\section{I-1.4. Reagents.}

All the reagents used in the experiment were of the analytical grade purity.

\section{1-2.. Experimental method.}

\section{I-2.1. Preparation of sample solution.}

The calculated amount of sample with the potassium chloride stock solution was diluted to $30 \mathrm{ml}$ with distilled water to make it $0.1 M$ in potassium chloride solution. Oxygen dissolved in the test solution was removed throughly by passing nitrogen gas of $99.99 \%$ purity.

\section{I-2.2. Measurement.}

Polarograms were taken 5-6 times for each solution at room temperature and the reproducibility was confirmed.

\section{Experimental Results}

\section{1-1. Effect of oxygen dissolved in the test solution.}

The effect of oxygen dissolved in solution on the polarographic waves was examined with three test solutions, that is, the first solution is saturated with the pure oxygen gas, from the second one is removed the dissolved oxygen by passing the pure nitrogen gas through the solution, and the third one undergoes no treatment. The polarograms of these test solutions are shown in Fig. 2. As will be seen from Fig. 2, in the first solution the polarogram indicated that the current increased nearly at $-0.8 \mathrm{~V} v$ s. S.C.E. In the second solution, the increase of current did not appear until $-1.3 \mathrm{~V}$ vs. S.G.E. It can be seen that oxygen must be purged.

\section{II-2. Polarographic waves of various ions.}

\section{II-2.1. Polarographic waves of metal ions.}

The polarographic waves of thallium (I), zinc (II), lead (II), and cobalt (II) ions were

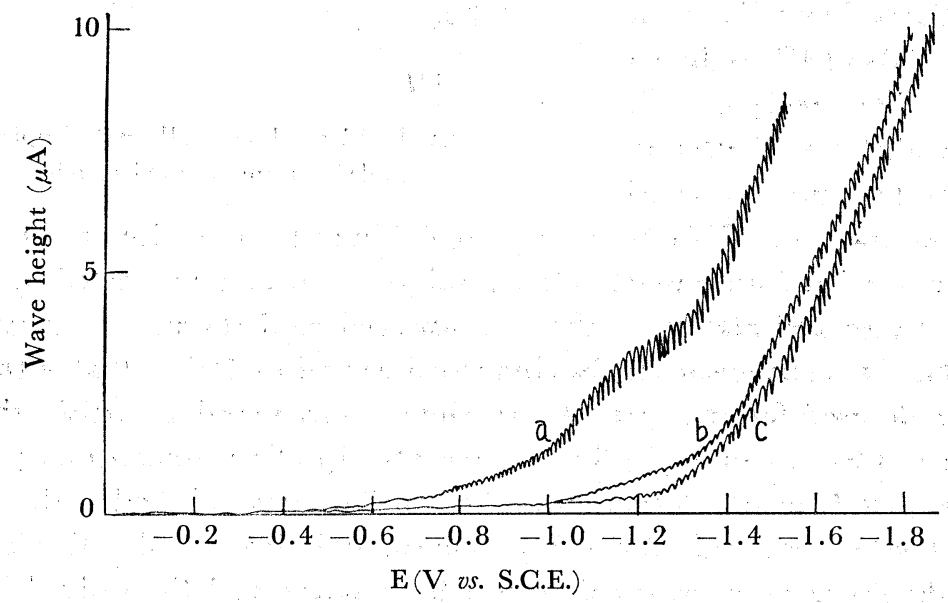

Fig. 2. Effect of oxygen dissolved in the electrolytic solution.

(a) The solution is saturated with the pure oxygen gas at room temperature.

(b) The solution without any treatment.

(c) The oxygen dissolved in the solution is removed by passing the pure nitrogen. 


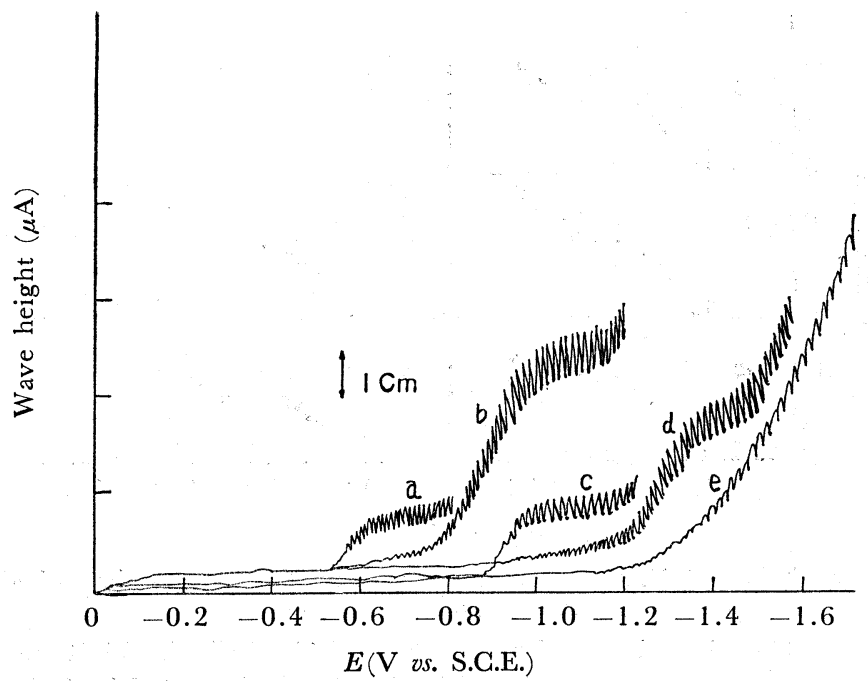

Fig. 3. Polarographic waves of various metal ions obtained with dipping type molybdenum microelectrode at $25^{\circ} \mathrm{C}$.

The concentration of metal ions and sensitivity of polarograph are
(a) $2.0 \times 10^{-3} M \mathrm{~Pb}(\mathrm{II})$ ion $(4.0 \mu \mathrm{A} / \mathrm{mm})$,
(b) $1.0 \times 10^{-3} M \mathrm{Tl}(\mathrm{I})$ ion $(0.8 \mu \mathrm{A} / \mathrm{mm})$,
(c) $4.5 \times 10^{-3} M \mathrm{Co}$ (II) ion $(4.0 \mu \mathrm{A} / \mathrm{mm})$,
(d) $1.0 \times 10^{-3} M \mathrm{Zn}$ (II) ion $(2.0 \mu \mathrm{A} / \mathrm{mm})$,
(e) $0.1 M \mathrm{KCl}$ solution $(0.08 \mu \mathrm{A} / \mathrm{mm})$.

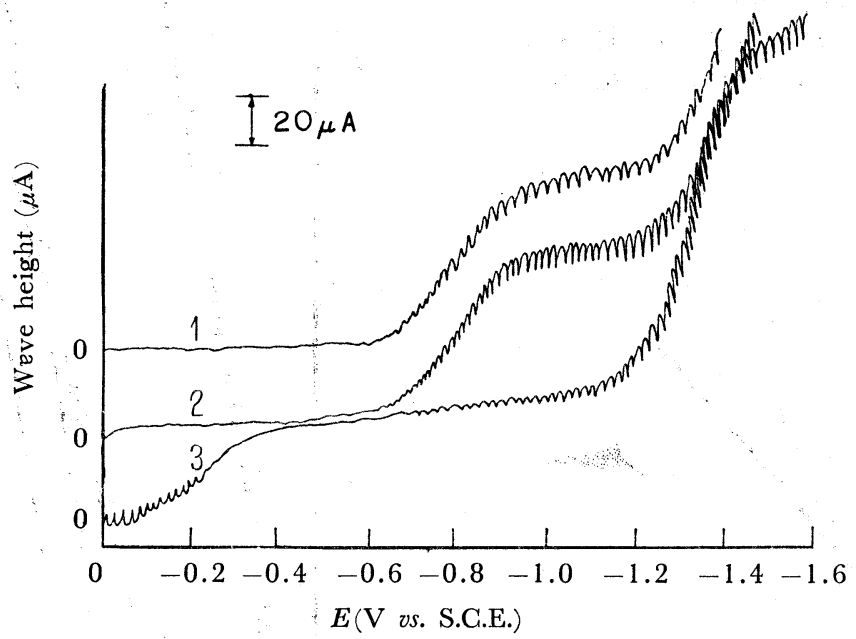

Fig. 4. Polarographic waves of hydrogen and hydroxyl ions obtained with dipping type molybenum microelectrode.

The concentration of $\mathrm{HCl}, \mathrm{HNO}_{3}$ and $\mathrm{KOH}$ are
(1) $1.0 \times 10^{-3} M \mathrm{HCl}$ in $0.1 \mathrm{M} \mathrm{KCl}$,
(2) $1.0 \times 10^{-3} \mathrm{M} \mathrm{HNO}_{3}$ in $0.1 \mathrm{M} \mathrm{KGl}$,
(3) $4.1 \times 10^{-3} M \mathrm{KOH}$ in $0.1 M \mathrm{KGl}$.

shown in Fig. 3. As will be seen from Fig. 3, reproducible waves appeared at about -0.7 $\mathrm{V}$. with thallium (I), $-1.2 \mathrm{~V}$. with zinc (II), $-0.5 \mathrm{~V}$. with lead (II) and $-0.9 \mathrm{~V}$. with cobalt (II) ion, respectively. 


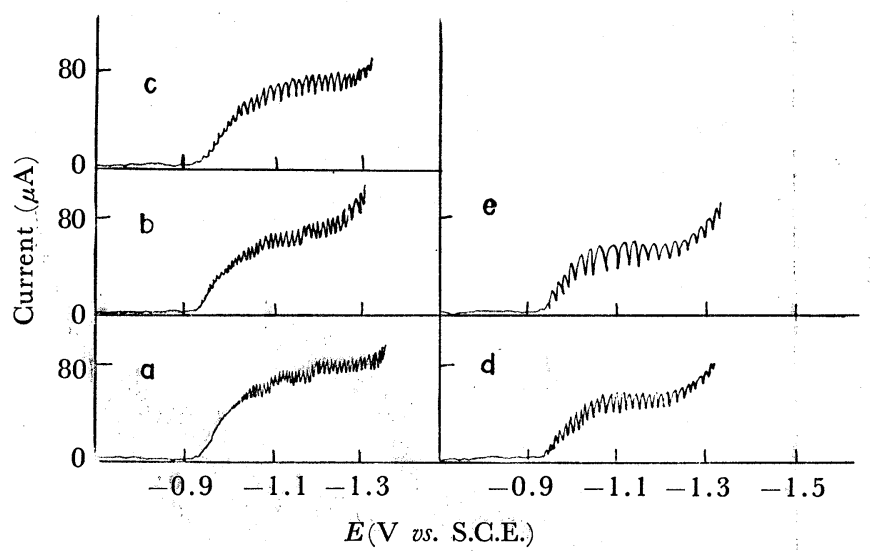

Fig. 5. Effect of the flow rate of nitrogen gas passed over the cathode surface on the polarographic wave.

The electrolytic solution : $6.6 \times 10^{-3} \mathrm{M}$. $\mathrm{CoCl}_{2}$ in $0.1 \mathrm{M} \mathrm{KGl}$.

Gas flow rate (sec./bubble) : a) 1.75, b) 2.30, c) 3.2, d) 4.65,

e) 6.20 .

\section{II-2.2. Polarographic weraves of hydrogen and hydroxyl ions.}

The typical polarographic wave of hydrogen ion in $1.0 \times 10^{-3} M$ as hydrochloric acid and nitric acid in $0.1 M$ potassium chloride is shown in Fig. 4(1) and (2), and also that of hydroxyl ion in $4.1 \times 10^{-3} M$ as potassium hydroxide in $0.1 M$ potassium chloride is shown in Fig. 4(3).

As will be seen from Fig. 4, with the hydrogen ion the electrode reaction began from about $-0.63 \mathrm{~V}$. and the half-

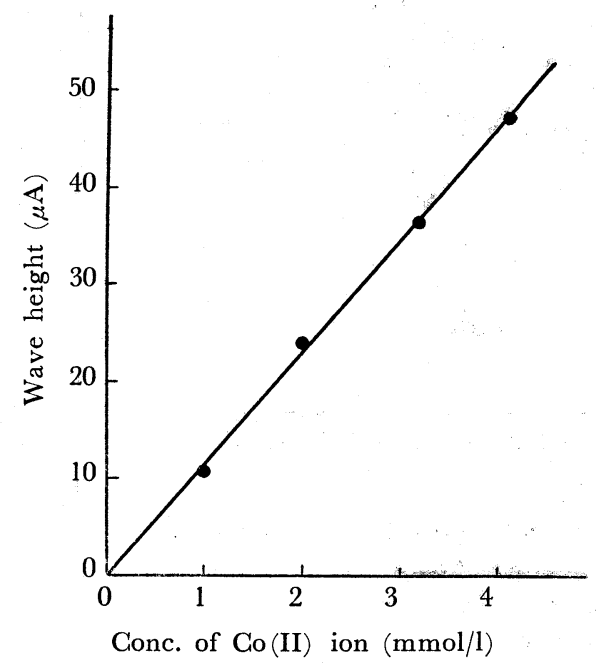

Fig. 6. Relationship between the concenration of $\mathrm{CoCl}_{2}$ and the limiting current.

Electrolytic solution : $\mathrm{CoCl}_{2}$ in 0.1 $M \mathrm{KCl}$.

Gas flow rate : $3.2 \mathrm{sec} /$ bubble.

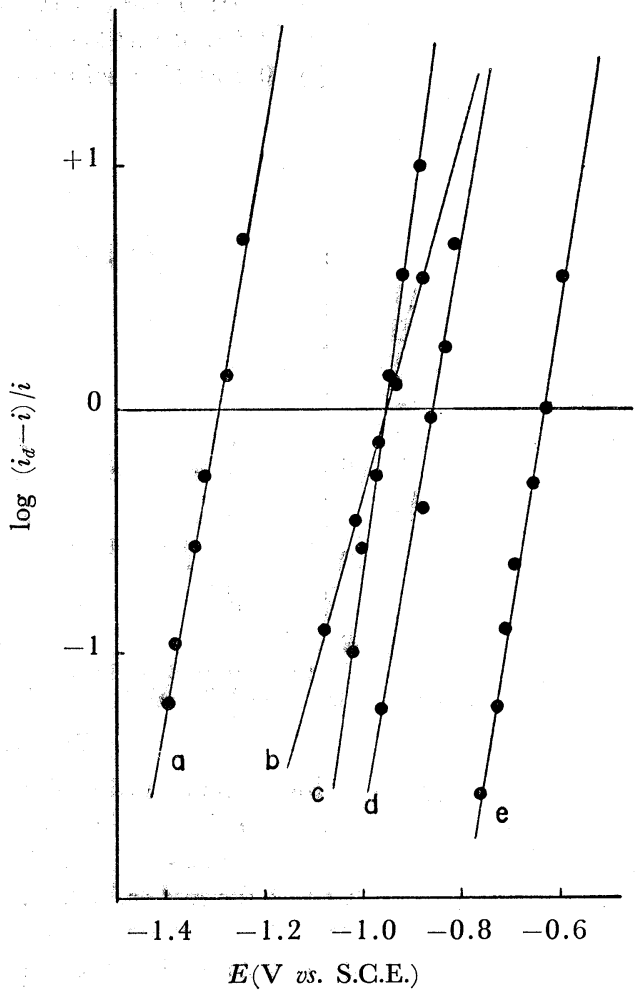

Fig. 7. Log plots of current-voltage curves of various metal ions. $a: \mathrm{Zn}(\mathrm{II})$ ion, $b: \mathrm{Tl}(\mathrm{I})$ ion, $c: \mathrm{Co}(\mathrm{II})$ ion, $d: \mathrm{Cd}(\mathrm{II})$ ion, $e: \mathrm{Pb}(\mathrm{II})$ ion. 
wave potential of the polarogram was $-0.79 \mathrm{~V}$. vs. S.C.E. In the case of hydroxyl ion, an anodic oxidation wave was observed and its half-wave potential was -0.23 V.vs. S.C.E.

\section{II-3. Relationship between the flow rate of nitrogen gas passed over the dipping cathode surface} and the polarographic wave height.

Experiments were carried out using $6.6 \times 10^{-3} \mathrm{M}$ cobaltous chloride in $0.1 \mathrm{M}$ potassium chloride. The results, as shown in Fig. 5, indicated that in the range of gas flow rate of 1.75-6.2 sec./bubble the wave height was almost unaffected. However, the increase in the gas flow rate resulted not only in the increase in wave height but also in the distorted wave form and it became difficult to obtain a stable limiting current.

In order to examine the streaming of the solution near the electrode, $0.1 \%$ erythrosine solution was gently poured into the electrode surface and the flow rates of gas were

Table I. Comparison of the calculated and the experimental values of the log plot slope.

\begin{tabular}{c|c|c|c}
\hline $\begin{array}{c}\text { Expected electrode } \\
\text { reaction }\end{array}$ & $\begin{array}{c}\text { Temperature } \\
\left({ }^{\circ} \mathrm{C}\right)\end{array}$ & $\begin{array}{c}2.3 R T / n F \\
\text { calculated } \\
(\mathrm{mV} .)\end{array}$ & $\begin{array}{c}\text { Slope of log } \\
\text { plot measure } \\
(\mathrm{mV})\end{array}$ \\
\hline $\mathrm{Tl}^{+}+\mathrm{e}=\mathrm{Tl}$ & 25 & 59 & 120 \\
$\mathrm{Cd}^{2+}+2 \mathrm{e}=\mathrm{Cd}$ & 25 & 30 & 70 \\
$\mathrm{Zn}^{2+}+2 \mathrm{e}=\mathrm{Zn}$ & 25 & 30 & 70 \\
$\mathrm{Co}^{2+}+2 \mathrm{e}=\mathrm{Co}$ & 25 & 30 & 50 \\
$\mathrm{~Pb}^{2+}+2 \mathrm{e}=\mathrm{Pb}$ & 25 & 30 & 40 \\
\hline
\end{tabular}

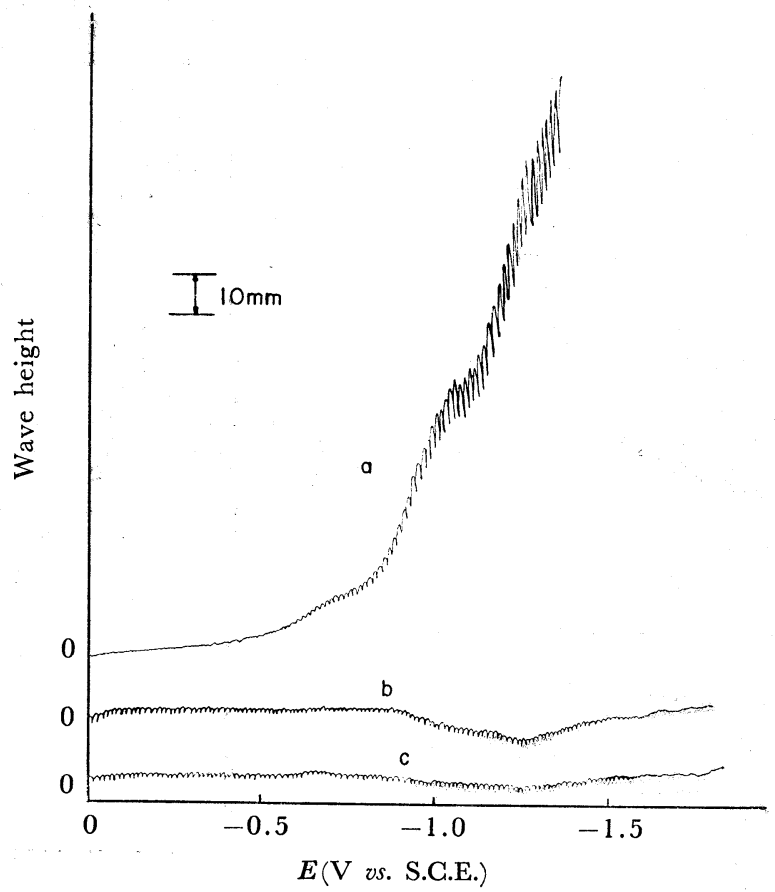

Fig. 8. DG andAC polarograms obtained with $\mathrm{CoCl}_{2}$ in $0.1 \mathrm{M} \mathrm{KGl}$.

$a$ : DC polarogram ; Damp. $=2000 \mathrm{~F}$, Sens. $=0.2 \mu \mathrm{A} / \mathrm{mm}$.

$b:$ AC polarogram ; Parallel capacitance $=5.0$, Sens. $=6.0 \mu \mathrm{A} / \mathrm{mm}$.

$c:$ AG polarogram ; Parallel capacitance $=5.0$, Sens. $=20.0 \mu \mathrm{A} / \mathrm{mm}$, 


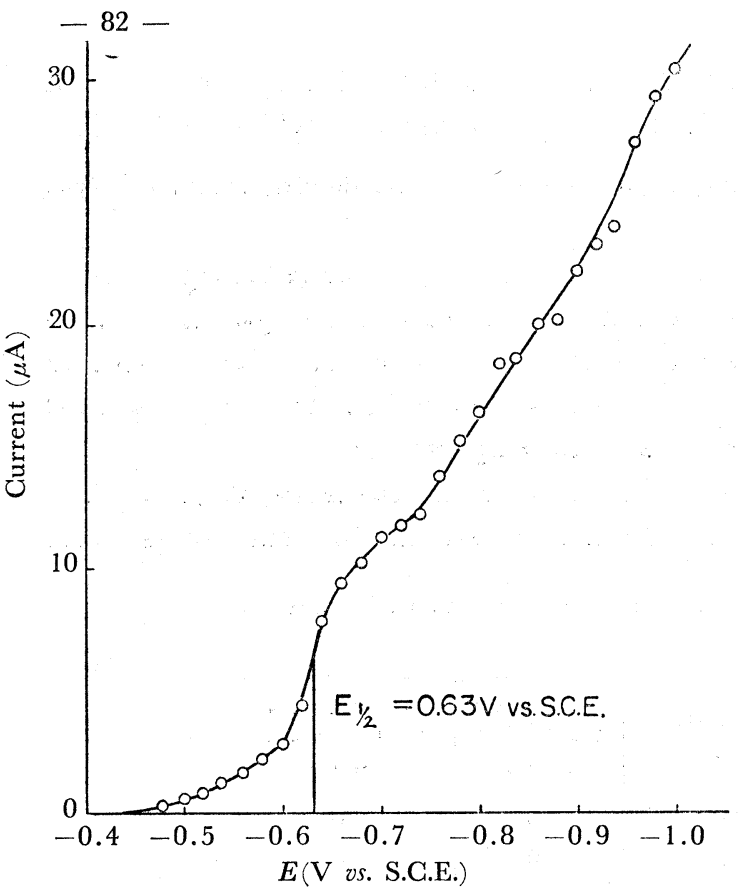

Fig. 9(a). Current-voltage curve of $\mathrm{Pb}(\mathrm{II})$ ion obtained with a dipping type molybdenum microelectrode.

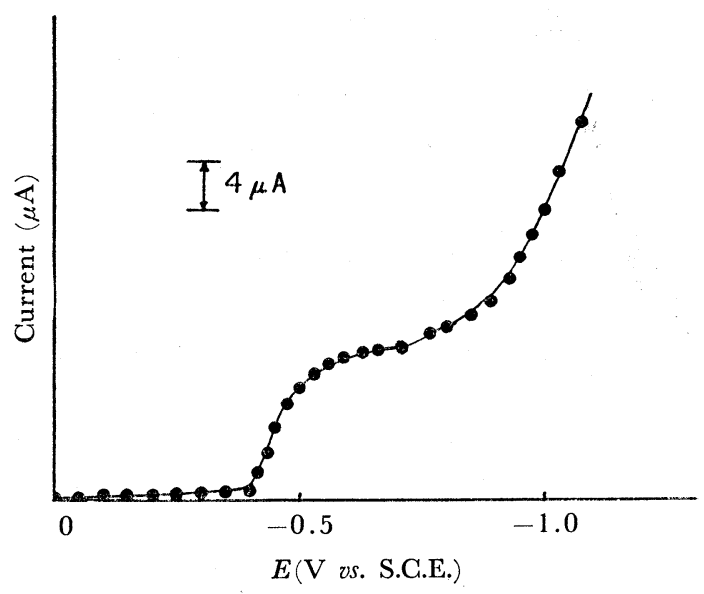

Fig. 9(c). Current-voltage curve of $\mathrm{Pb}(\mathrm{II})$ ion obtained with a stationary molybdenum microelectrode.

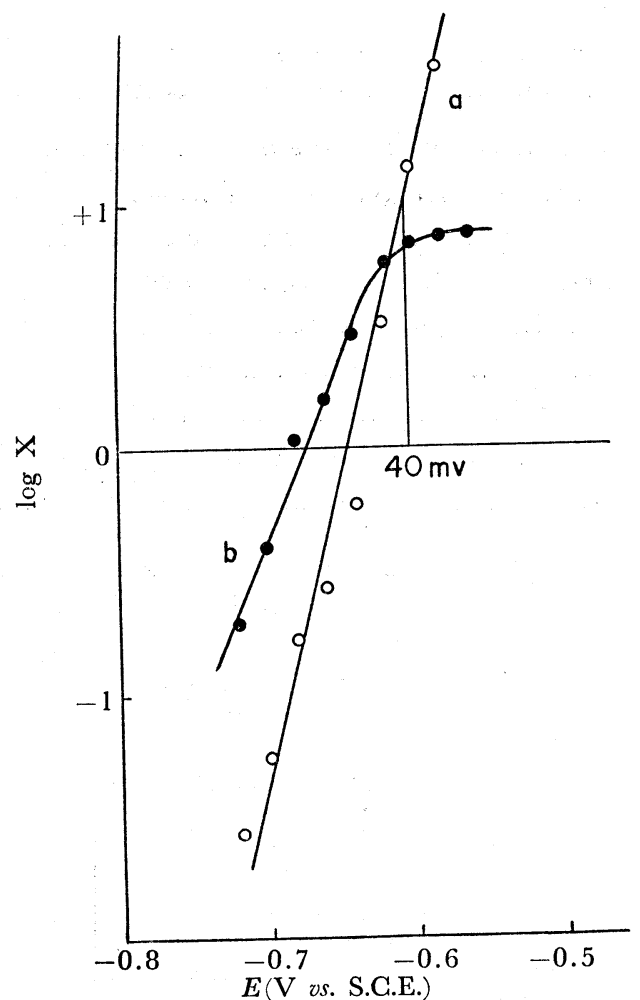

Fig. 9(b). Log plots of current-voltage curve of $\mathrm{Pb}$ (II) ion obtained with a dipping type molybdenum microelectrode. $a: E \sim \log \left(i_{d}-i\right) / i, b: E \sim \log \left(i_{d} \sim i\right)$.

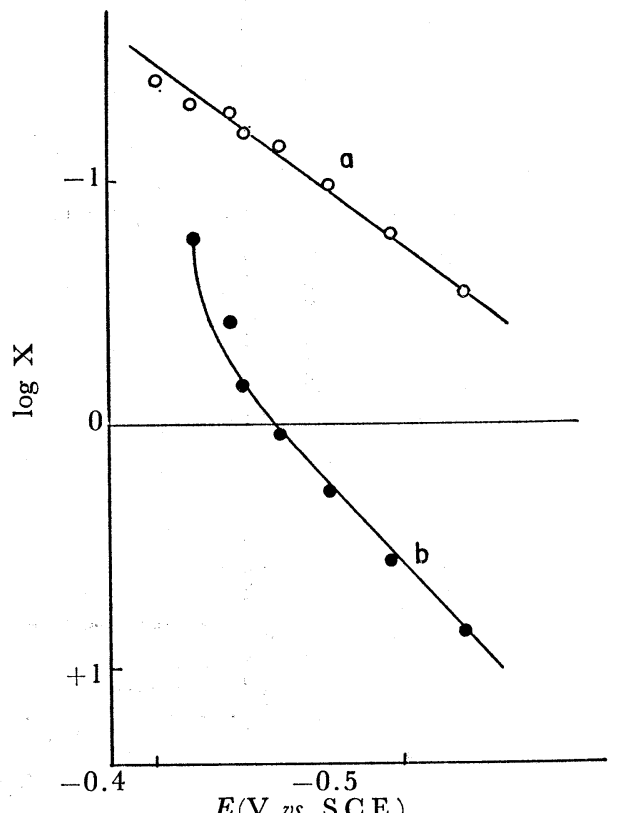

Fig. 9(d). Log plots of current-voltage curve of $\mathrm{Pb}(\mathrm{II})$ ion obtained with a stationary molybdenum microelectrode.

$a: E \sim \log \left(i_{d}-i\right) / i, b: E \sim \log \left(i_{d}-i\right)$, 
varied. It was observed that the irregular movement of the solution near the electrode surface did not occur in the range of gas flow rate of 3.5-5.0 sec./bubble.

\section{II-4. Relationship between the concentration of depolarizer and the limiting current.}

The relationship between the concentration of reducible ion and limiting current of polarographic wave was examined in the concentration range of $1.0-4.2 \times 10^{-3} M$ of cobaltous chloride solution and the result obtained is indicated in Fig. 6.

The limiting current was directly proportional to the concentration in this range and the ratio of the limiting current to the concentration $\left(i_{d} / C\right)$ was $1.08 \times 10^{4} \mu \mathrm{A} / M$. The same experiment was carried out with the concentration range of $0.35-3.5 \times 10^{-3} M$ of cadmium nitrate in $0.1 M$ potassium chloride solution, the limiting current of which was directly proportional to the concentration in this range and the ratio of the limiting current to the concentration $\left(i_{d} / C\right)$ was $1.00 \times 10^{4}, \mu \mathrm{A} / M$.

The half-wave potential in these concentrations was nearly constant, i.e., in the case of cobaltous ion it was $-0.950 \pm 0.005 \mathrm{~V}$. vs. S.C.E., and that of cadmium (II) ion $-0.85 \pm$ 0.01 V.vs. S.C.E., both independent on the scanning rate of applied potentials (3.2 and 4.8 $\mathrm{mV} . / \mathrm{sec}$.)

\section{II-5. Current-voltage curves of various metal ions.}

The log plots of the current-voltage curves of various metal ions, as shown in Fig. 3, are given in Fig. 7. As will be seen from Fig. 7, the relation of $\log \left(i_{d}-i\right) / i$ against the applied voltage showed a straight line with all these metal ions. The values of the slopes calculated by $2.3 R T / n F$ and by the log plots with the experimental polarograms are shown in Table I.

DC and AC polarograms obtained with cobaltous chloride are shown in Fig. 8. The plots of current against applied voltage of lead (II) ion obtained by using the dipping type and the stationary molybdenum microelectrodes, are shown in (a) and (c) on Fig. 9 and the log plots of these curves (a) and (c) are shown in (b) and (d) in Fig. 9.

\section{Discussion}

As will be seen from the experimental results well-defined polarograms were obtained with the dipping type molybdenum microelectrode in aqueous solutions.

The limiting current tended to increase slightly with the incresing flow rate of gas, but it was almost unaffected and remained constant in the range of "gas flow rate of 1.7$6.2 \mathrm{sec} . / \mathrm{bubble}$. However, the increase in the gas flow rate resulted not only in the increase of wave height but also in deterioration of the wave from and it became difficult to obtain a reproducible limiting current. This may be attributed to the difficulty in obtaining a stable diffusion layer by the irregular stirring in the solution near the electrode surface, accompanied with the higher rate of gas flow, as was found by the experiment with a colored solution. Consequently, in order to obtain a favorable and reproducible polarogram, the flow rate of gas should necessarily be controlled between 3.0-5.0 sec./bubble. If the electrode surface is kept constant, from the experimental results described in the II-4, the limiting current $i_{d}$ of the polarographic wave of metal ion can be represented by the following equation under the above-stated experimental conditions.

$$
i_{d}=K \cdot C
$$

Here, $C$ is the concentration of reducible ions and $K$ is a proportionality constant(limiting current constant), 
It is most interesting that the applied voltage plotted against $\log \left(i_{d}-i\right) / i$ was a straight line, but the plot of applied voltage against $\log \left(i_{d}-i\right)$ did not produce a straight line. However, the slope of the applied voltage plotted against $\log \left(i_{d}-i\right) / i$ has a larger value than the value which is expected when electrode reaction is reversible. The half-wave potential remained nearly constant with the change of the concentration of reducible species and of the scanning rate of applied voltage. An AG polarograph peak was not observed with cobaltous ion with this electrode. From these experimental facts, the electrode reaction should be considered to be completely irreversible, as will be discussed in detals later in following report.

\section{Conclusion}

(1) An improved dipping type microelectrode was proposed, in which molybdenum wire was used instead of platinum and the shape of the electrode tubing was modified. Well-defined and reproducible polarograms was obtained by means of the improved electrode.

(2) The flow rate of gas passed over the cathode surface hardly affected the wave height in the range of $3.0-5.0 \mathrm{sec} . / \mathrm{bubble}$.

(3) The wave height was directly proportional to the concentration of reducible species and the half-wave potential remained constant. The results suggest that qualitative and quantative analyses are possible by use of the improved electrode.

(4) The plot of the applied voltage against $\log \left(i_{a^{-}}-i\right) / i$ for several metal ions was a straight line, the slope of which was greater than the value $2.3 R T / n F$, which should be observed in the case of a reversible electrode process. The AC polarographic peak was not observed under the same condition. The electrode reaction concerned should be considered to be irreversible.

\section{Acknowledgment}

The author expressed his gratitude to Professors Hidehiro Goto and Shin Suzuki of the Research Institute for Iron, Steel and Other Metals, Tohoku University, for their helpful discussions and criticisms on the experimental work and preparation of manuscript.

The author also expressed his thanks to Professor Tomihito Kambara of the Department of Chemistry, Hokkaido University, for his many valuable suggestions.

\section{Literature}

1) Yu. Lialikov, V. Karmazin, Zavodskaya Laboratoria, 14, 144 (1948).

2) N. Nachtrieb, M. Steinberg, J. Am. Chem. Soc., 70, 2613 (1948).

3) Y.K. Delimarski, E.M. Skovets, L.S. Berenblyum, Zhur. Friz. Khim. 22, 1103 (1948).

4) E.L. Colichman, Anal. Chem., 27, 1559 (1955).

5) H. Goto, S. Suzuki, M. Saito, J. Chem. Soc., Japan, Pure Chem. Sec. (Nippon Kagaku Zasshi), 83, 883 (1962).

6) J. Yoshimura, “Theory and Measurement of pH” (1955), Maruzen Co.

7) G.J. Hills, J.E. Oxley, Z. Anal. Ghem., 173, 51 (1960). 
改良浸漬型モリブデン微小電極によるポーラログラフ的研究

（I）承溶液由のポーラログラフィー

斎藤節

(菓北大学教鏊部化学科)

従来の浸漬型微小電極の液と接する部分の形態を改 良した浸漬型モリブデン微小電極による水溶液のポー ラログラフィールついて基整的な检討家行ない, 本電 極による水溶液のポーラログラフ的研究への河能性变 確かめた.

（1）電解液中の溶存酸素のポーラログラム：室温で 酸素を飽和した電解液では， $-0.77 \mathrm{~V} v$. S.G.E. 付 近から電流が増大して，なだらかな波を生じホホーラ ログラムを妨害する。 それに対して高純度空素ガスで 溶存酸素を追い出した電解液では $-1.3 \mathrm{~V}$ vs. S.C.E. 付近まで電流の增大がなかった。

(2) 種々のイオン，ポーラログラフ波: $0.1 N \mathrm{KCl}$ 中の $\mathrm{Tl}^{+}, \mathrm{Zn}^{2+}, \mathrm{Pb}^{2+}, \mathrm{Co}^{2+}, \mathrm{H}^{+}$および $\mathrm{OH}^{-}$イオン について, 再現性あるポーラログラムが得られた。 $\mathrm{OH}^{-}$イオンを除く上記の諸イオン结, 陰極邉元波を

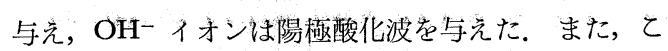
れらのポーラログラムは, 滴下水銀電極によって得ら れる波㔙に相似した $\mathrm{S}$ 字形であった。

(3) 陰極表面への窒素ガスの通気速度とポーラログ ラムの関係: 通気速度が1.75〜6.2秒/気泡の間では, 波高および波形认影響を及ほさないが，1.75秒/気泡 以上となると波高加㳄第に増大し，波形も䔡くなるた
め, 一定の限界電流が得られなくなる。乙の理由を調 ベるために着色した水溶液を電極付近へ静かに流し込 み, 通気速度を種々飞变光た場合の霆極付近の夜の流 動状態を観察したととろ, 通気速度が 3.0〜 5.0秒/気 泡では不規則なカキマゼが起っていないととが確かめ られた。

(4) 復極剂濃度と波高の関係: ポーラログラムの波 高と復極剤濃度の関係を $\mathrm{Co}^{2+} お よ ひ ゙ ~ \mathrm{Cd}^{2+}$ そつい 調べた。波高は濃度に比例するととが磼かめられた。 すなわち， $\mathrm{Co}^{2+}$ および $\mathrm{Cd}^{2+}$ の $i_{d} / \mathrm{G}$ はそれぞれ $1.08 \times 10^{4}$ および $1.00 \times 10^{4} \mu \mathrm{A} / M$ であった. また $\mathrm{E}_{1 / 2}$ は復極剤の濃度変化および加電圧走查速度の变化 によって変化せず，つねに一定値を与光た。

(5) 種々の金属イオンのポーラログラムの電流一電 压の関係: $E \sim \log \left(i_{d}-i\right) / i \quad$ の関係は植線となるのに対 して $E \sim \log \left(i_{d}-i\right)$ の関係は直線とならない. しかし $E \sim \log \left(i_{d}-i\right) / i$ の直線の傾斜は, 電極反応が可逆的で あるとした場合の理論值 $(2.3 R T / n F)$ より大きい值 を与えた。ささらに本電極は交流ポーラログラフによる ピークを与えない(本文図8) したがって, 本電極反 応恈可逆的に進行するものと推定される。 